\title{
COMMENT
}

\section{Is the CTC dye technique an adequate approach for estimating active bacterial cells?}

\author{
S. Ullrich ${ }^{1, *}$, B. Karrasch ${ }^{2}$, H.-G. Hoppe ${ }^{1}$ \\ ${ }^{1}$ Institut für Meereskunde, Universität Kiel, Düsternbrooker Weg 20, D-24105 Kiel, Germany \\ ${ }^{2}$ Umweltforschungszentrum Leipzig-Halle GmbH, Gewässerforschung, Brückstr. 3a, D-39114 Magdeburg, Germany
}

In the paper 'Coherence of microbial respiration rate and cell-specific bacterial activity in a coastal planktonic community' by Smith (1998), Aquat Microb Ecol $16: 27-35$, the author, using the fluorogenic tetrazolium dye 5-cyano-2,3 ditolyl tetrazolium chloride (CTC)-as a measure of cell-specific metabolic activity, and comparing the numbers of $\mathrm{CTC}$ reducing cells with respiratory activity, reported that $\mathrm{CTC}$-active $(\mathrm{CTC}+)$ cell abundance was highly correlated with respiration rates within the microplankton community, explaining $80 \%$ or more of the variations in these rates. This finding is a new and interesting observation which had not previously been reported.

However, the fraction of CTC+ cells made up on average only $14 \%$ of the total bacterial numbers although a eutrophic site, Chesapeake Bay, was investigated. The author concluded that this low fraction of CTC+ bacteria '...is likely responsible for the bulk of bacterial community metabolic activity...'. On the other hand, the portion of active bacteria has been reported to be 25 to $94 \%$ of total bacterial numbers using 2 ( $p$-iodo-phenyl)-3-p-(nitrophenyl)-5 phenyltetrazolium chloride INT in the same environment (Tabor \& Neihof 1984). To explain this discrepancy the less direct coupling of INT to respiratory activity compared to CTC was cited (Smith \& McFeters 1996, 1997), necessarily leading '...to lower estimates of that fraction of the total population quantitatively engaged in respiratory metabolism...' But does this mean that INT-positive bacteria can be neglected with respect to the metabolic activity of bacterial communities?

There are, indeed, a number of methods which yield distinctly higher levels of metabolically active bacterial cells compared to the CTC method. In a recent study of

\footnotetext{
•E-mail: sullrich@ifm.uni-kiel.de
}

marine bacterial assemblages (aged offshore water compared to rich harbour water), metabolically active bacteria were simultaneously determined using different methods (Karner \& Fuhrman 1997). In this study, universal 16S rRNA probe counts averaged about half of the corresponding DAPI counts and were highly correlated to microautoradiographic counts (using a $\left[{ }^{3} \mathrm{H}\right]$ amino acid mixture), while the number of CTC+ cells were 2 orders of magnitude below DAPI counts, and thus well below the estimates obtained using the other methods. In another study, CTC+ counts were compared to esterase active cells (Yamaguchi \& Nasu 1997). While CTC+ cells amounted to only 10 to $15 \%$ and $30 \%$ of total bacteria numbers in an unpolluted and a highly polluted river, respectively, esterase active cells made up 50 and $90 \%$, respectively.

As mentioned by Smith (1998), low fractions of active cells were generally reported if the in situ activity of natural communities was determined using CTC (e.g. Schaule et al. 1993, Gasol et al. 1995, Choi et al. 1996, Lovejoy et al. 1996, Ullrich et al. 1996, Kalmbach et al. 1997, Karner \& Fuhrman 1997, Yamaguchi \& Nasu 1997). But the conclusion (derived from the correlation between the number of CTC-reducing cells and respiration) that CTC+ cells are '...responsible for the bulk of community processes such as production and respiration...' can be misleading in this generalised form. The low portions of active cells generally observed under natural conditions using the CTC method may be instead due to methodological uncertainties related to this approach. For example, it was observed that several bacterial strains tested were difficult to stain with CTC (Yamaguchi \& Nasu 1997). Smith \& McFeters (1997 and literature cited therein) reported that some active bacteria do not reduce CTC under certain conditions. Furthermore, it is known from a number of investigations that the portion of CTC-reducing 
bacteria increased with greater nutrient concentrations (e.g. Rodriguez et al. 1992, Schaule et al. 1993, Smith et al. 1994, Smith \& McFeters 1996 and literature cited therein, Kalmbach et al. 1997). Only a few exceptions to this pattern have been reported so far (Coallier et al. 1994, Pyle et al. 1995). Therefore, the use of CTC might be problematic if the method is applied to study sites characterised by low nutrient concentrations. Karner \& Fuhrman (1997) reported CTC+ counts below $1 \%$ of DAPI counts for a marine environment (Santa Monica Bay). In the central Arabian Sea (oligotrophic conditions), CTC+ counts amounted to about 2 to $3 \%$ of total bacteria numbers, clearly ranging below counts determined by microautoradiography ( 6 to $46 \%, \mathrm{n}=11$ ). Even under coastal upwelling conditions off the Omani coast (enhanced nutrient conditions), the portion of CTC+ bacteria made up only $7 \%$ of total bacterial counts (Ullrich et al. unpubl. data).

Indeed, it is uncertain whether the CTC method is a suitable approach for the determination of the actual number of respiring bacteria. The relationship between $\mathrm{CTC}$ reduction and $\mathrm{CO}_{2}$ production was recently investigated in mixed microbial communities under changing nutrient conditions (Cook \& Garland 1997). A general lack of coincidence between the formazancontaining cell population and changes in respiration was found, contradicting the view that CTC reduction and respiration are generally closely linked. Inhibitory effects of CTC on bacterial respiration and metabolic activity were reported by Ullrich et al. (1996). There was evidence from this investigation that bacterial production (calculated from $\left[{ }^{3} \mathrm{H}\right]$ leucine uptake) and respiration $\left(\left[{ }^{14} \mathrm{C}\right.\right.$ gglucose $)$ were greatly reduced to $1-14 \%$, and $4-44 \%$, respectively, by the addition of CTC compared to untreated controls, leading to an underestimation of actively respiring cells by CTC. Additionally, inhibitory effects of CTC were demonstrated by means of luminescence in a Microtox bioassay. CTC concentrations of 0.1 and $5.0 \mu \mathrm{M}$ required only $15 \mathrm{~min}$ for decreases of approximately 50 and $100 \%$, respectively. Furthermore, it was calculated that the low fraction of active cells determined by the CTC method would result in unrealistically high per cell production and implausibly short generation times.

Aany of these critical results were not considered or discussed in the commented paper. The number of actively respiring cells might be underestimated due to the methodological insufficiencies of the CTC method mentioned above. Even if CTC+ cells represent the most active bacteria (as claimed by Smith), this pattern cannot be clearly defined and standardised. Not taking into account the results of former publications, Smith concluded that the CTC method '...provides an ecologically meaningful measure of active bacterial abundance...' This general view is inconsistent with the results of the comparative methodological studies cited here. One must distinguish between the number of CTC-reducing bacteria determined in special in situ conditions, and the actual number of active bacteria as determined by more sensitive methods.

\section{LITERATURE CITED}

Choi JW, Sherr EB, Sherr BF (1996) Relation between presence-absence of a visible nucleoid and metabolic activity in bacterioplankton cells. Limnol Oceanogr 41.(6): $1161-1168$

Coallier J, Prévost M, Rompré A (1994) The optimization and application of two direct viable count methods for bacteria in distributed drinking water. Can J Microbiol 40:830-836

Cook KL, Garland JL (1997) The relationship between electron transport activity as measured by CTC reduction and $\mathrm{CO}_{2}$ production in mixed microbial communities. Microb Ecol 34:237-247

Gasol JM, del Giorgio PA, Massana R. Duarte CM (1995) Active versus inactive bacteria: size-dependence in a coastal marine plankton community. Mar Ecol Prog Ser 128:91-97

Kalmbach S, Manz W, Szewzyk U (1997) Dynamics of biofilm formation in drinking water: phylogenetic affiliation and metabolic potential of single cells assessed by formazan reduction and in situ hybridization. FEMS Microbiol Ecol 22:265-279

Karner M, Fuhrman JA (1997) Determination of active marine bacterioplankton: a comparison of universal 16S rRNA probes, autoradiography, and nucleoid staining. Appl Environ Microbiol 63:1208-1213

Lovejoy C, Legendre $L$, Klein B, Tremblay JÉ, Ingram RG, Therriault JC (1996) Bacterial activity during early winter mixing (Gulf of St. Lawrence, Canada). Aquat Microb Ecol 10:1-13

Pyle BH, Broadaway SC, McFeters GA (1995) A rapid, direct method for enumerating respiring enterohemorrhagic Escherichia coli $\mathrm{O} 157: \mathrm{H7}$ in water. Appl Environ Microbiol 61:2614-2619

Rodriguez GG, Phipps D, Ishiguro K, Ridgway HF (1992) Use of a fluorescent redox probe for direct visualization of actively respiring bacteria. Appl Environ Microbiol 58: 1801-1808

Schaule G, Flemming HC, Ridgway HF (1993) Use of 5 cyano-2,3-ditolyl tetrazolium chloride for quantifying planktonic and sessile respiring bacteria in drinking water. Appl Environ Microbiol 59:3850-3857

Smith EM (1998) Coherence of microbial respiration rate and cell-specific bacterial activity in a coastal planktonic community. Aquat Microb Ecol 16:27-35

Smith JJ, McFeters GA (1996) Effects of substrates and

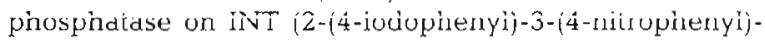
5-phenyl tetrazolium chloride) and CTC (5-cyano-2,3ditolyl tetrazolium chloride) reduction in Escherichia coli. J Appl Bacteriol 80:209-215

Smith JJ, McFeters GA (1997) Mechanisms of INT (2-(4iodophenyl)-3-(4-nitrophenyl)-5-phenyl tetrazolium chloride), and CTC (5-cyano-2,3-ditolyl tetrazolium chloride) reduction in Escherichia coli K-12. J Microb Methods 29: $161-175$

Smith JJ, Howington JP, McFeters GA (1994) Survival, physiological response, and recovery of enteric bacteria exposed to a polar marine environment. Appl Environ Microbiol 60:2977-2984 
Tabor PS, Neihof RA (1982) Improved method for determination of respiring individual microorganisms in natural waters. Appl Environ Microbiol 43:1249-1255

Ullich S, Karrasch B, Hoppe HG, Jeskulke K, Mehrens M (1996) Toxic effects on bacterial metabolism of the redox dye 5-cyano-2,3-ditolyl tetrazolium chloride. Appl Environ Microbiol 62(12):4587-4593

Yamaguchi N, Nasu M (1997) Flow cytometric analysis of bacterial respiratory and enzymatic activity in the natural aquatic environment. J Appl Microbiol 83:43-52 